\title{
Antimutagenicity and antigenotoxicity of Aloe arborescens Miller and Aloe barbadensis Miller in Aspergillus nidulans and Wistar rats
}

\author{
A.P. Berti ${ }^{1}$, G.F. Palioto ${ }^{2}$ and C.L.M.S.C. Rocha ${ }^{3}$ \\ ${ }^{1}$ Curso de Ciências Biológicas, Universidade Estadual de Mato Grosso do Sul, \\ Dourados, MS, Brasil \\ ${ }^{2}$ Departamento de Ensino e Pesquisa, Universidade Federal Tecnológica do Paraná, \\ Apucarana, PR, Brasil \\ ${ }^{3}$ Departamento de Biotecnologia, Genética e Biologia Celular, \\ Universidade Estadual de Maringá, Maringá, PR, Brasil \\ Corresponding author: A.P. Berti \\ E-mail: alessandrabiologa@hotmail.com
}

Genet. Mol. Res. 15 (3): gmr. 15038522

Received February 1, 2016

Accepted June 2, 2016

Published September 2, 2016

DOI http://dx.doi.org/10.4238/gmr.15038522

Copyright (C 2016 The Authors. This is an open-access article distributed under the terms of the Creative Commons Attribution ShareAlike (CC BY-SA) 4.0 License.

\begin{abstract}
Medicinal plants such as Aloe arborescens Miller and Aloe barbadensis Miller are used by the general population to treat various diseases. Therefore, the aim of this study was to evaluate the antimutagenicity of these two species using a meth $G 1$ system in Aspergillus nidulans and the comet assay in rats. The animals were treated with the plants at concentrations of 360 and $720 \mathrm{mg} / \mathrm{kg}$ body weight ( 1 and 2, respectively) by gavage for 14 days, followed by the administration of etoposide on treatment day 8. Blood samples were prepared for analysis of DNA damage. For the test in A. nidulans, the biAlmethG1 lineage conidia were treated for $4 \mathrm{~h}$ with both plant species at concentrations of 4 and $8 \%(\mathrm{w} / \mathrm{v})$. Then, they were washed
\end{abstract}


and plated on a selective medium for frequency analysis of survival and mutation. The results of the comet assay showed that both plants were antigenotoxic compared to etoposide, which was not a typical response of methGl systems, where only the highest concentration of plant extracts usually exhibit beneficial effects. This study demonstrates the potential antigenotoxicity and antimutagenicity of the Aloe plants tested and, therefore, supports their use as a form of preventive therapy and for health maintenance by the population.

Key words: Medicinal plants; Aloe; Etoposide; Comet assay; methG1 system

\section{INTRODUCTION}

The interactions between genetic and environmental factors such as diet and lifestyle, especially in relation to nutrition and physical inactivity, can promote the progression of diseases such as obesity, diabetes, and cancer, which is currently dramatically increasing in prevalence in epidemic proportions (Phillips, 2013). This can be attributed to the constant exposure of the cells of all living organisms to exogenous and endogenous agents, which damages the genetic information because DNA molecules are not static, and their bases are constantly susceptible to change (Erdtmann, 2003).

Carcinogenesis is initiated by an irreversible alteration of DNA replication and cell proliferation that is activated to repair the initial mutation, which indicates a direct relationship clearly exists between mutagenicity and carcinogenicity (Loureiro et al., 2002). Therefore, cancer is a consequence of the progressive accumulation of random mutations in individuals who are prone to the development of this disease. Therefore, the use of antimutagenic substances in the prevention of cancer by decreasing the rate of mutation has been investigated (Liviero and von Borstel, 1996).

Etoposide is one of the most widely used chemotherapeutic agents for the treatment of numerous cancers. It acts by inducing lesions in the genome such as breakage of one or both strands of the DNA, causing cytotoxicity to sick cells; however, it also affects healthy cells (David et al., 2001). Chemotherapy shocks the immune system and drastically weakens the organism and, therefore, an appropriate diet is necessary to improve the immunity of the patient.

Aloe arborescens Miller and Aloe barbadensis Miller are Aloe species that possess great medicinal value (Singh et al., 2000), and are widely used by the general Brazilian population. These plants have several activities that are beneficial to the body, and in particular, their antioxidant (Ojha et al., 2011), antitumoral (Tomasin and Gomes-Marcondes, 2011), antidiabetic (Misawa et al., 2008; Abo-Youssef and Messiha, 2013), and immune system stimulating (Lissoni et al., 2009; Picchietti et al., 2013) functions stand out.

The present study aimed to evaluate the possible antimutagenic actions of $A$. arborescens and $A$. barbadensis in methG1 system Aspergillus nidulans and the antigenotoxicity by using the comet assay in rats.

\section{MATERIAL AND METHODS}

\section{Reagents}

The chemotherapeutic agent, etoposide (ETO), was purchased as the branded product,

Genetics and Molecular Research 15 (3): gmr.15038522 
Posidon $^{\circledR}(100 \mathrm{mg})$ from Darrow Laboratory. For the comet assay, low melting point (LMP) and normal melting point agarose were obtained from Invitrogen while all other reagents were from Merck.

\section{Treatments}

The mucilage was obtained from the fresh leaves of $A$. arborescens and $A$. barbadensis, after the removal of the shell and gel extraction (parenchyma). The mucilage of the leaves of each species was processed in a blender and then filtered through a $20-\mathrm{mm}$ pore size filter paper (Millipore, for the antimutagenicity experiments). The gels were diluted in water to obtain the required dose and immediately used for the treatments and was not stored.

\section{Comet assay in rats}

\section{Animals}

Each experimental group consisted of five male Wistar rats (Rattus norvegicus) obtained from the Central Biotery of Universidade Estadual de Maringá (UEM). In the vivarium, the rats were housed under controlled conditions of $25^{\circ} \mathrm{C}$ temperature, $50 \%$ humidity, and a 12-h light/dark photoperiod, while water and ration feed were provided ad libitum. The animal experiments were initiated only after a 1-week acclimatization. In addition, all the ethical principles, protocols, and regulations of the animal experimentation laboratory were in strict accordance with the international standards established. Furthermore, the project was approved by the Institutional Ethics Committee of UEM and the Ethics Committee on Animal Use in Research/UEM and followed the Ethical Principles in Animal Experimentation established by the Brazilian College of Animal Experimentation. Moreover, specific treatment protocols were used for the sample collection and comet assay.

\section{Treatments}

Each group consisted of five randomly assigned male rats, weighing approximately $100 \mathrm{~g}$ body weight (bw). The negative controls (CO) received $0.1 \mathrm{~mL} / 100 \mathrm{~g}$ (bw) mineral water, and the positive controls were treated with ETO, while the four test groups received the A. arborescens and A. barbadensis mucilage at two different doses, 360 and $720 \mathrm{mg} / \mathrm{kg}$ bw (1 and 2 , respectively) via gavage for 14 days. In addition, another four groups received the same treatment with both plant species but were administered ETO $(50 \mathrm{mg} / \mathrm{kg} \mathrm{bw})$, intraperitoneally on day 8 . The $\mathrm{CO}$ and four test substance control groups (A1, A2, B1, B2) received $0.1 \mathrm{~mL} / 100$ $\mathrm{g}$ bw $0.9 \%$ saline solution. The blood was collected from all groups before, $1,24 \mathrm{~h}$, and 7 days after administration of ETO and saline. In summary, the groups were treated for 14 days according to the experimental protocol shown in Table 1.

\section{Comet assay}

The comet assay was performed in accordance with the methods of Singh et al. (1988) and Tice et al. (2000). Briefly, a 5- $\mu$ L blood sample was withdrawn from the tail of each animal, added to $120 \mu \mathrm{L}$ LMP agarose [0.5\% phosphate-buffered saline (PBS)], the mixture

Genetics and Molecular Research 15 (3): gmr.15038522 
was pre-applied onto two slides covered with normal agarose (1.5\% PBS), and then cooled to $4^{\circ} \mathrm{C}$ for $5 \mathrm{~min}$. Then, the slides were immersed in the lysis solution at $4^{\circ} \mathrm{C}$ [ $4.5 \mathrm{M}$ sodium chloride, $\mathrm{NaCl} ; 100 \mathrm{mM}$ ethylene diaminetetra acetic acid (EDTA); 10 mMTris, $\mathrm{pH}$ 10.0; $1 \%$ Triton-X; and $10 \%$ dimethyl sulfoxide] for $24 \mathrm{~h}$. Then, the slides were incubated in the electrophoresis buffer (300 mM sodium hydroxide, $\mathrm{NaOH}$ and $200 \mathrm{mM}$ EDTA, $\mathrm{pH}>13$ ) at $4^{\circ} \mathrm{C}$ for $25 \mathrm{~min}$, and the electrophoresis $(300 \mathrm{~mA}, 0.7 \mathrm{~V} / \mathrm{cm})$ was subsequently performed for $25 \mathrm{~min}$. Then, the slides were neutralized thrice ( $5 \mathrm{~min}$ each) in a neutralization solution $(0.4 \mathrm{M}$ Tris-hydrochloride, $\mathrm{HCl}, \mathrm{pH} 7.5)$, fixed with absolute ethanol for $5 \mathrm{~min}$, dried at temperature $25^{\circ} \mathrm{C}$ temperature, and then held at $4^{\circ} \mathrm{C}$ before the analysis. The slides were stained with 20 $\mu \mathrm{L}$ ethidium bromide $(20 \mathrm{mg} / \mathrm{mL})$, coverslipped, and then analyzed by using a fluorescence microscope.

Table 1. Grouping of Wistar rats treated with Aloe arborescens and Aloe barbadensis in comet assay.

\begin{tabular}{l|l}
\hline Group & Treatment \\
\hline CO & Water, on the 8th day, saline injection \\
\hline ETO & Water, on the 8th day, etoposide injection \\
\hline A1 & {$[1]$ A. arborescens, on the 8th day, saline injection } \\
\hline A2 & {$[2]$ A. arborescens, on the 8th day, saline injection } \\
\hline B1 & {$[1]$ A. barbadensis, on the 8th day, saline injection } \\
\hline B2 & {$[2]$ A. barbadensis on the 8th day, saline injection } \\
\hline A2 + ETO & {$[1] A$. arborescens, on the 8th day, etoposide injection } \\
\hline B1 + ETO & {$[2] A$. arborescens, on the 8 th day, etoposide injection } \\
\hline B2 + ETO & {$[1] A$. barbadensis, on the 8 th day, etoposide injection } \\
\hline
\end{tabular}

Fifty cells on each slide, totaling 100 cells per animal were analyzed in a blind fashion to determine the percentage of damaged cells per animal and the frequency of damage (FD). Each damaged cell was graded on a scale of 0 to 4 according to the size of the comet tail to determine the index of damage (ID), which was calculated by multiplying the number of cells in each level to obtain the final value. Thus, the values ranged from 0 (no damaged cells, $0 \mathrm{x}$ 100 ) to 400 (all cells were maximally damaged, 4 x 100).

\section{methG1 system in $A$. nidulans}

\section{Lineage}

The biAlmeth 1 lineage used in this experiment originated from Glasgow (Scotland). The strain was deficient in biotin (chromosome I) and methionine (chromosome IV).

\section{Culture media}

The culture media were prepared according to the method of Pontecorvo et al. (1953) and Clutterbuck (1974). Complete medium (CM) was used to cultivate the biA1methG1 strain while the selective medium (SM) used for the analysis of the mutants consisted of minimal medium supplemented with biotin $(0.02 \mathrm{mg} / \mathrm{mL})$. The medium used to evaluate the survival was prepared, and it contained the same composition as the SM and was supplemented with $50 \mathrm{mg} / \mathrm{mL}$ methionine (SMM).

Genetics and Molecular Research 15 (3): gmr.15038522 


\section{Treatments}

The dormant conidia of the biAlmethG1 strain were treated as follows: Control, distilled water; $A$. arborescens $(4 \% \mathrm{w} / \mathrm{v}) ;$ A. arborescens $(8 \% \mathrm{w} / \mathrm{v}) ;$ A. barbadensis $(4 \% \mathrm{w} / \mathrm{v})$; A. barbadensis $(8 \% \mathrm{w} / \mathrm{v})$.

\section{Concentration determination}

The effects of different concentrations of the mucilage from the leaves of the two Aloe species were tested on the germination of the fungus. These results were used to determine suitable concentrations for treating the conidia, and 4 and $8 \%(w / v)$ were selected for each plant species.

\section{Mutagenicity test}

The conidia of the colonies grown for 5 days at $37^{\circ} \mathrm{C}$ in $\mathrm{CM}$ were collected, agitated, filtered through glass wool, and then subjected to different treatments. The treatment time was set at $4 \mathrm{~h}$ depending on the nutritional value of the gels because the conidia tend to germinate when they are left for periods longer than $4 \mathrm{~h}$, and the method requires dormant conidia. After the treatment, the conidia were washed and centrifuged thrice with distilled water. For the survival estimation, appropriate dilutions were prepared, and $0.1 \mathrm{~mL}$ of each was added to 10 plates containing SMM for each treatment, and this was incubated for 3 days at $37^{\circ} \mathrm{C}$. For the analysis of the mutation, $0.1 \mathrm{~mL}$ was inoculated into the suspension without the dilution on 10 plates containing SM for each treatment, and the plates were incubated for 5 days at $37^{\circ} \mathrm{C}$. The entire procedure was repeated in triplicate.

\section{Statistical analysis}

The statistical analysis of the results of the meth $G 1$ system experiments was performed according to the method of Munson and Goodhead (1977), which was adapted to the methG1 system by Scott et al. (1982). The results of the comet assay were analyzed using the Tukey test $(\mathrm{P}<0.001)$.

\section{RESULTS}

Table 2 shows that the groups of animals treated with the plant substances exhibited no genotoxicity because the IDs of their treatments were not statistically different from those of the negative control animals. The results of the ID determination of the samples collected after 7 days (14 days of gel treatment) show that both concentrations of $A$. arborescens reduced the basal damage observed in the negative control animals. The effects in the animals that received the chemotherapy and plant treatments were statistically different from the group that received only ETO for the two blood samples evaluated ( 1 and $24 \mathrm{~h}$ later). The samples were not collected after 7 days and, therefore, could not be analyzed because the vast majority of the chemotherapy-treated animals died before then.

Genetics and Molecular Research 15 (3): gmr.15038522 
Table 2. Index of damage and standard deviation of Wistar rat groups treated with Aloe arborescens and Aloe barbadensis in comet assay.

\begin{tabular}{l|c|c|c}
\hline Treatment & $1 \mathrm{~h}$ & $24 \mathrm{~h}$ & 7 days \\
\hline CO & $6.40 \pm 2.97^{*}$ & $1.40 \pm 1.52^{*}$ & $11.20 \pm 4.76$ \\
\hline A1 & $8.00 \pm 6.590$ & $3.80 \pm 5.49$ & $3.80 \pm 2.49$ \\
\hline A2 & $6.80 \pm 4.60$ & $4.60 \pm 3.91$ & $2.80 \pm 2.95$ \\
\hline B1 & $1.00 \pm 0.70$ & $8.40 \pm 3.51$ & $5.20 \pm 4.08$ \\
\hline B2 & $2.60 \pm 1.50$ & $3.00 \pm 5.10$ & $4.80 \pm 4.08$ \\
\hline ETO & $170.4 \pm 57.50$ & $104.00 \pm 41.20$ & - \\
\hline A1 ETO & $38.00 \pm 27.59^{*}$ & $45.8 \pm 20.62^{*}$ & - \\
\hline A2 + ETO & $34.40 \pm 4.16^{*}$ & $22.20 \pm 8.23^{*}$ & - \\
\hline B1+ETO & $16.60 \pm 9.37^{*}$ & $29.40 \pm 15.09^{*}$ & - \\
\hline B2+ ETO & $29.80 \pm 16.65^{*}$ & $38.80 \pm 4.76^{*}$ & - \\
\hline
\end{tabular}

Treatments for 14 days: CO: water, on 8th day, saline injection; ETO: water, on 8th day, etoposide injection; A1: [1] A. arborescens, on 8th day, saline injection; A2: [2] A. arborescens, on the 8th day, injection of saline; B1: [1] A. barbadensis, on 8th day, saline injection; B2: [2] A. barbadensis on 8th day, saline injection; A1 + ETO: [1] $A$. arborescens, on 8th day, etoposide injection; A2 + ETO: [2] A. arborescens, on 8th day, etoposide injection; B1 + ETO: [1] A. barbadensis, on 8th day, etoposide injection; B2 + ETO: [2] A. barbadensis, on 8th day, etoposide injection. *Statistically significant compared to ETO.

The mean FD (Table 3) and the observed ID showed that treatment with the two gels was not genotoxic. The groups that were administered each plant substance (babosa) and the chemotherapy showed lower values than the ETO-treated group did for the analysis of the 1- and 24-h samples, which was indicative of antigenotoxicity. The samples collected after 7 days revealed that the groups treated with the gels did not show any statistically significant difference, although the values were lower than that of the control.

Table 3. Average frequency of damage and standard deviation of Wistar rat groups treated with Aloe arborescens and Aloe barbadensis in comet assay.

\begin{tabular}{l|c|c|c}
\hline Treatment & $1 \mathrm{~h}$ & $24 \mathrm{~h}$ & 7 days \\
\hline CO & $3.80 \pm 1.30^{*}$ & $0.80 \pm 0.45^{*}$ & $5.80 \pm 2.77$ \\
\hline ETO & $79.20 \pm 19.84$ & $54.40 \pm 17.82$ & - \\
\hline A1 & $5.00 \pm 4.00$ & $2.80 \pm 4.08$ & $1.80 \pm 1.09$ \\
\hline A2 & $5.20 \pm 3.70$ & $3.40 \pm 2.79$ & $3.80 \pm 1.64$ \\
\hline B1 & $1.00 \pm 0.70$ & $5.80 \pm 2.28$ & $3.00 \pm 2.00$ \\
\hline B2 & $2.00 \pm 1.00$ & $2.00 \pm 2.91$ & - \\
\hline A1 +ETO & $22.20 \pm 14.60^{*}$ & $25.40 \pm 9.53^{*}$ & - \\
\hline A2+ETO & $19.40 \pm 2.19^{*}$ & $14.00 \pm 4.53^{*}$ & - \\
\hline B1+ETO & $9.20 \pm 5.49^{*}$ & $17.40 \pm 7.99^{*}$ & - \\
\hline B2+ETO & $19.00 \pm 9.40^{*}$ & $18.00 \pm 2.83^{*}$ & \\
\hline
\end{tabular}

Treatments for 14 days: CO: water, on 8th day, saline injection; ETO: water, on 8th day, etoposide injection; A1: [1] A. arborescens, on 8th day, saline injection; A2: [2] $A$. arborescens, on 8th day, saline injection; B1: [1] $A$. barbadensis, on 8th day, saline injection; B2: [2] A. barbadensis on 8th day, saline injection; A1 + ETO: [1] $A$. arborescens, on 8th day, etoposide injection; A2 + ETO: [2] A. arborescens, on 8th day, etoposide injection; B1 + ETO: [1] A. barbadensis, on 8th day, etoposide injection; B2 + ETO: [2] A. barbadensis, on 8th day, etoposide injection. *Statistically significant compared to ETO.

We observed that from the second day after the intraperitoneal injection, all the ETOtreated animals presented with symptoms of weakness, loss of hair, diarrhea, and weight loss. Furthermore, most of these animals did not survive up to day 7 when the last blood sample analysis was to be performed based on the experimental design of the comet assay. Animal deaths were observed from day 3 after the administration of the chemotherapy while all the animals treated with only ETO died. However, some of the animals in the groups treated with the two Aloe species survived: groups A1, A2, B1, and B2 had one, two, four, and two surviving rats, respectively. 
Table 4 presents the results of the mutagenicity evaluation in the meth $G 1$ system. At a concentration of $4 \%$, both gels decreased the frequency of mutation but did not increase the viability, which is why the statistical analysis showed no significance. However, at a concentration of $8 \%$, the gels increased the survival and decreased the frequency of mutation, and the results were significant.

\begin{tabular}{|c|c|c|c|c|}
\hline Experiment & Treatment & No. of viable conidia $\times 10^{5} / \mathrm{mL}$ & No. mutant $/ \mathrm{mL}$ & Mutant frequency \\
\hline \multirow[t]{3}{*}{1} & $\mathrm{C}$ & 70.13 & 52.66 & 12.30 \\
\hline & A4 & 40.23 & 71.66 & 18.30 \\
\hline & B4 & 44.87 & 83.66 & 19.07 \\
\hline \multirow[t]{2}{*}{2} & $\mathrm{C}$ & 98.04 & 45.66 & 4.60 \\
\hline & A8 & 146.19 & 38.33 & 3.09 \\
\hline \multirow[t]{2}{*}{3} & $\mathrm{C}$ & 50.21 & 35 & 7.02 \\
\hline & B8 & 5511 & 33.66 & 636 \\
\hline
\end{tabular}

A4: Aloe arborescens (4\%), A8: A. arborescens (8\%), B4: Aloe barbadensis (4\%), B8: A. barbadensis (8\%). Statistical analysis of treatment results using method of Munson and Goodhead (1977) produced the following straight slope: A4: $\mathrm{m}^{\prime}=9.15, \mathrm{~m} "=18.30, \mathrm{mc}=10.81 ; \mathrm{A} 8: \mathrm{m}{ }^{\prime}=1.54, \mathrm{~m} "=3.09, \mathrm{mc}=3.87 ; \mathrm{B} 4: \mathrm{m}^{\prime}=9.53, \mathrm{~m} "=$ $19.07, \mathrm{mc}=15.04 ; \mathrm{B} 8: \mathrm{m}^{\prime}=3.18, \mathrm{~m} "=6.36, \mathrm{mc}=7.09$.

\section{DISCUSSION}

The leaves of the plants surveyed in this study were not genotoxic when tested in isolation since they induced a similar degree of genetic lesions to the spontaneously induced lesions in the control group. This result provides evidence supporting the potential safety of the therapeutic use of these plants, which is in agreement with the results obtained by Munhoz et al. (2012), who evaluated three concentrations of a commercial $A$. barbadensis juice in mice using the comet assay. In addition, Ruiz et al. (1996) and Sturbelle et al. (2010) performed in vitro assays using $A$. nidulans and in vivo micronucleus tests in rats.

The statistical differences in both the median ID and FD between the group of animals treated with ETO and the Control, confirmed the genotoxicity of the chemotherapy, justifying its use as a positive control. Furthermore, the analysis of the group treated with ETO alone and all the groups that received the ETO in combination with the plant gel treatments demonstrated the antigenotoxic activity of the Aloe species at all the concentrations. This result indicated the protective action of the leaves of the Aloe species tested.

The animals in the ETO group showed a complete mortality after the chemotherapy, in contrast with the groups that received the chemotherapy in combination with the Aloe plant species, which had survivors. These results corroborate those of Lissoni et al. (2009) who studied the effects of several chemotherapies including ETO that was used in this study, in patients with cancer. Their results confirmed the multiple benefits experienced by patients who were administered chemotherapy in combination with the A. arborescens compared with the group that only received chemotherapy. The average number of lymphocytes observed after the chemotherapy was significantly higher in the patients who were also treated with the plant and the incidences of symptoms such as weakness and fatigue were lower, which correlated with the increase in the length of survival of these patients as well as the improvement in their quality of life.

The effects of the Aloe mucilage in this study corroborated those reported by Von Borstel et al. (1996), who found that numerous compounds derived from plants that were 
administered in combination with chemotherapy prevented the damage these antineoplastic agents caused to healthy cells. Furthermore, Singh et al. (2000) reported that the extract of Aloe vera $\mathrm{L}$. (synonymous with $A$. barbadensis) showed antioxidant activity and positively influenced the enzymes associated with the metabolism of carcinogens. This finding was based on a survey conducted in vivo, which confirmed the ability of the modular to reduce and even eliminate the toxicity of other biological agents (Davis, 1997).

Düsman (2007) demonstrated the antimutagenic activity of $A$. barbadensis by analyzing the chromosomal aberrations in Wistar rats, in relation to cyclophosphamide, another chemotherapeutic agent that is widely used to treat various cancers. However, according to Sturbelle et al. (2010), the same plant species exhibit antimutagenicity when combined with the mutagenic paracetamol. This effect was demonstrated in a micronucleus test using human lymphocytes and by antigenotoxicity evaluation of its commercial form in miceusing the comet assay in relation to the agent methyl methanesulfonate in a post-treatment assessment by Munhoz et al. (2012).

Furthermore, the protective effects of the A. barbadensis gel were confirmed by Gbadegesin et al. (2009) in a study with mice exposed to petroleum products (diesel, kerosene, and hydraulic oil) in tests that investigated the factors associated with both hepatotoxicity and mutagenicity. Therefore, the antigenotoxic activity of the $A$. arborescens and $A$. barbadensis gels were compared with the effects of ETO in Wistar rats, and the results corroborated the information reported in most of the previously reported scientific studies described here.

The protective activity of $A$. arborescens and $A$. barbadensis observed in our present study suggest the involvement of multiple mechanisms such as the inhibition of genotoxic effects, antioxidant activity, inhibition of cell proliferation, and modulation of signal transduction. Many of these mechanisms are interconnected or partially overlap with various stages of the DNA repair process (Kojima et al., 1992; Kuroda et al., 1992).

The powerful effect of the substances contained in the Aloe plants was demonstrated by their ability to increase the exercising activity, as well as their antidiabetic and antioxidant effects (Abo-Yousseef and Messiha, 2013). Furthermore, the Aloe plants blocked the replication of the human immunodeficiency virus, which was mediated by their immunomodulatory properties, as was demonstrated by the method described by Yu et al. (2009) and Toliopoulos et al. (2012).

In view of the strong association between the antimutagenic and anticarcinogenic potential, it is worth highlighting the study performed by Tomasin and Gomes-Marcondes (2011), who detected the antitumoral activity of $A$. vera L. and honey in Wistar rats, which controlled tumor growth, decreased cellular proliferation, and increased the apoptosis of cancer cells. The phytochemical composition of $A$. barbadensis mainly consists of anthraquinones, mucilage, polysaccharides, fatty acids, sterols, glycoproteins, enzymes, amino acids, minerals, and vitamins, which are responsible for the numerous therapeutic and nutritional benefits that are attributed to this plant (Choi and Chung, 2003). Aloctin A is an active substance extracted from $A$. arborescens, which has several biological and proven pharmacological activities such as antitumoral and anti-inflammatory. In addition, aloctin A is a promising candidate immunomodulatory agent (Imanishi, 1993).

Only the highest concentration (8\%) of the two species tested in the A. nidulans meth $G 1$ system showed antimutagenic activity that was statistically significant, suggesting a dose-response effect. However, the 4\% concentration reduced the frequency of spontaneous mutations compared to the Control, which suggests the mucilage of the leaves may possess

Genetics and Molecular Research 15 (3): gmr.15038522 
antioxidant effects. This system-test is efficient and has been used in other investigations of phytotherapeutic products such as the study by Rodrigues et al. (2003) on the mushroom of the Sun (Agaricus blazei) and Souza-Paccola et al. (2004) who investigated the Lentinula edodes and $A$. blazei mushrooms.

It is also worth noting that according to Berti et al. (2015), both species surveyed in this study positively interfered in the development of several cell lines (normal and mutant) of A. nidulans. These effects included the stimulation of germination and a significant reduction in the dead or malformed conidia or both, which proved the potential benefit of these plants based on their ability to contribute to the homeostasis of organisms and their antioxidant activities, as well as the stimulation of self-protection and self-preservative activities.

The results of the present study apparently contradict those obtained by Kayraldiz et al. (2010) in a survey of the antigenotoxicity extract of $A$. vera $\mathrm{L}$. investigated in chromosomal aberration, micronuclei, sister chromatid exchange, and Ames tests. The extract was genotoxic at all concentrations used in the test for chromosomal aberrations and cytotoxicity in human lymphocytes. We also observed that this plant did not increase the sister chromatid exchange, which is indicative of its beneficial effects. However, Sirdaarta and Cock (2010) reported that the juice of A. barbadensis showed toxic effects by inducing oxidative stress, similarly to what was described by Tian and Hua (2005), who demonstrated that the components of this plant such as Aloe-emodina and Aloin can act as pro-oxidants or as antioxidants, depending on their concentration.

Mehrabian et al. (2012) evaluated the antimutagenic effect of the ethanol and aqueous extract of $A$. barbadensis from two different cities in Iran using the Ames test. Both samples reduced the rate of mutation; however, the plant that originated from one of cities showed a maximum reduction of mutations, indicating that environmental factors have an impact on the antioxidant components of plants.

The therapeutic effects of medicinal plants or other natural products are not usually associated with the active substance, which, despite being the main component for a specific activity, may not be as effective when isolated. This phenomenon is due to the synergism between the substances, which occurs as a means of mutual assistance between the plant components (Davis, 1993). The constituents of $A$. arborescens and A. barbadensis include the polysaccharides acemanan and glicomanan, which act as immunomodulators, and the anthraquinone, Aloeemodina that has antitumor activities (Pecere et al., 2000; Lissoni et al., 2009).

The results of the present study largely support previously published reports of the beneficial properties of $A$. arborescens and A. barbadensis, suggesting that its consumption is potentially beneficial as a preventive therapy and for health maintenance, especially in individuals exposed to chemotherapy. These results also support the need for additional studies on the effects of the continuous internal use of these plants.

\section{REFERENCES}

Abo-Youssef AMH and Messiha BAS (2013). Beneficial effects of Aloevera in treatment of diabetes: Comparative in vivo and in vitro studies. Bull Facul. Pharm. Cairo Univ. 51: 7-11.

Berti AP, Pacheco LS and Rocha CLMSC (2015). Efeito da Aloe arborescens Miller e da Aloe barbadensis Miller sobre o desenvolvimento vegetativo em Aspergillus nidulans. Rev. Bras. Pl. Med. 17: 534-542. http://dx.doi. org/10.1590/1983-084X/14_027

Choi $\mathrm{S}$ and Chung M (2003). A Review on the relationship betweemAloevera components and their biologic effects. Semin. Integr. Med. 1: 53-62. http://dx.doi.org/10.1016/S1543-1150(03)00005-X

Clutterbuck AJ (1974). Aspergillus nidulans. In: Handbook of Genetics (KING RC, ed.). Plenum Publishing, New York.

Genetics and Molecular Research 15 (3): gmr.15038522 
David JP, Silva EF, Moura DL, Guedes MLS, et al. (2001). Lignanas e triterpenos do extrato citotóxico de Eriope Blanchetii. Quim. Nova 24: 730-733. http://dx.doi.org/10.1590/S0100-40422001000600004

Davis RH (1993). Biological activity of Aloe vera. SOFW J. 119: 646-649.

Davis RH (1997). Aloe vera: A scientific approach. Vantage Press Incorporated, New York.

Düsman E (2007). Estudo da atividade antimutagênica da planta Babosa (Aloe vera L.), em ratos Wistar. Monografia Bacharel em Ciências Biológicas, Universidade Estadual de Maringá, Maringá.

Erdtmann BA (2003). Genotoxicidade nossa de todososdias. In: Genética Toxicológica (Silva J, Erdtman B and Henriques JAP). Alcance, Porto Alegre.

Gbadegesin MA, Odunola OA, Akinwumi KA and Osifeso OO (2009). Comparative hepatotoxicity and clastogenicity of sodium arsenite and three petroleum products in experimental Swiss Albino Mice: the modulatory effects of Aloe vera gel. Food Chem. Toxicol. 47: 2454-2457. http://dx.doi.org/10.1016/j.fct.2009.07.002

Imanishi K (1993). Aloctin A, an active substance of Aloe arborescens Miller as immuno-modulator. Phytother. Res. 7: S20-S22. http://dx.doi.org/10.1002/ptr.2650070708

Kayraldiz A, Yavuz Kocaman A, Rencuzoğullari E, Istifli ES, et al. (2010). The genotoxic and antigenotoxic effects of Aloe vera leaf extract in vivo and in vitro. Turk. J. Biol. 34: 235-246.

Kojima H, Konishi H and Kuroda Y (1992). Combined mutagenicity of methyl methanesulfonate and ethyl methanesulfonate in Chinese hamster V79 cells. Mutat. Res. 266: 171-180. http://dx.doi.org/10.1016/0027-5107(92)90184-4

Kuroda Y, Jain AK, Tezuka H and Kada T (1992). Antimutagenicity in cultured mammalian cells. Mutat. Res. 267: 201209. http://dx.doi.org/10.1016/0027-5107(92)90064-9

Lissoni P, Rovelli F, Brivio F, Zago R, et al. (2009). A randomized study of chemotherapy versus biochemotherapy with chemotherapy plus Aloe arborescens in patients with metastatic cancer. In Vivo 23: 171-175.

Liviero L and von Borstel RC (1996). The 4th International Conference on Mechanisms of Antimutagenesis and Anticarcinogenesis: a summary. Mutat. Res. 350: 287-293. http://dx.doi.org/10.1016/0027-5107(95)00104-2

Loureiro APM, Mascio PD and Medeiros MHG (2002). Formação de adutos exocíclicos com bases de DNA: Implicações em mutagênese e carcinogênese. Quim. Nova 25: 777-793. http://dx.doi.org/10.1590/S0100-40422002000500014

Mehrabian S, Majd A, Jonoubi P and Kheiri A (2012). A study of the antimutagenic effects of different extracts of Aloe vera leaf gel and latex using Ames test. J. Arak. Univ. Med. 15: 100-106.

Misawa E, Tanaka M, Nomaguchi K, Yamada M, et al. (2008). Administration of phytosterols isolated from Aloe vera gel reduce visceral fat mass and improve hyperglycemia in Zucker diabetic fatty (ZDF) rats. Obes. Res. Clin. Pract. 2: I-II. http://dx.doi.org/10.1016/j.orcp.2008.06.002

Munhoz BJP, Leffa DD, Mazzorana D, Paganini AD, et al. (2012). Avaliação do Potencial Antigenotóxico do suco de Aloe vera (Aloe barbadensis, Miller) em camundongos. Rev. Inova Saúde 1: 130-145.

Munson RJ and Goodhead DT (1977). The relation between induced mutation frequency and cell survival--a theoretical approach and an examination of experimental data for eukaryotes. Mutat. Res. 42: 145-160. http://dx.doi.org/10.1016/ $\underline{\mathrm{S} 0027-5107(77) 80019-5}$

Ojha S, Pandey M, Saraf S and Sonker K (2011). Aloe vera gel: A potent nutraceutical. J. Nat. Pharm. 21: 36-41.

Pecere T, Gazzola MV, Mucignat C, Parolin C, et al. (2000). Aloe-emodin is a new type of anticancer agent with selective activity against neuroectodermal tumors. Cancer Res. 60: 2800-2804.

Phillips CM (2013). Nutrigenetics and metabolic disease: current status and implications for personalised nutrition. Nutrients 5: 32-57. http://dx.doi.org/10.3390/nu5010032

Picchietti S, Bernini C, Belardinelli MC, Ovidi E, et al. (2013). Immune modulatory effects of Aloe arborescens extract on the piscine SAF-1 cell line. Fish Shellfish Immunol. 34: 1335-1344. http://dx.doi.org/10.1016/j.fsi.2013.02.019

Pontecorvo G, Roper JA, Hemmons LM, MacDonald KD, et al. (1953). The genetics of Aspergillus nidulans. Adv. Genet. 5: 141-238. http://dx.doi.org/10.1016/S0065-2660(08)60408-3

Rodrigues SB, Jabor IAS, Marques-Silva GG and Rocha CLMSC (2003). Avaliação do potencial antimutagênico do Cogumelo do Sol (Agaricus blazei) no sistema methG1 em Aspergillus (=Emericella) nidulans. Acta Sci. Agron. 25: 513-517.

Ruiz AR, Armenteros AE, González AV, Parra AV, et al. (1996). Evaluacion genotoxica de un extracto acuoso de Aloe vera L. Rev. Cuba. Planta Med. 1: 18-23.

Scott BR, Dorn GL, Käfer E and Stafford R (1982). Aspergillus nidulans: systems and results of tests for induction of mitotic segregation and mutation. II. Haploid assay systems and overall response of all systems. A report of the U.S. EPA Gene-Tox Program. Mutat. Res. 98: 49-94. http://dx.doi.org/10.1016/0165-1110(82)90003-3

Singh NP, McCoy MT, Tice RR and Schneider EL (1988). A simple technique for quantitation of low levels of DNA damage in individual cells. Exp. Cell Res. 175: 184-191. http://dx.doi.org/10.1016/0014-4827(88)90265-0

Singh RP, Dhanalakshmi S and Rao AR (2000). Chemomodulatory action of Aloe vera on the profiles of enzymes

Genetics and Molecular Research 15 (3): gmr.15038522 
associated with carcinogen metabolism and antioxidant status regulation in mice. Phytomedicine 7: 209-219. http:// dx.doi.org/10.1016/S0944-7113(00)80006-9

Sirdaarta J and Cock IE (2010). Effect of Aloe barbadensis Miller juice on oxidative stress biomarkers in aerobic cells using Artemia franciscana as a model. Phytother. Res. 24: 360-364. http://dx.doi.org/10.1002/ptr.2946

Souza-Paccola EA, Bomfeti CA, Fávaro LCL, Fonseca ICB, et al. (2004). Antimutagenic action of Lentinula edodes and Agaricus blazei on Aspergillus nidulans conidia. Braz. J. Microbiol. 35: 311-315. http://dx.doi.org/10.1590/S1517$\underline{83822004000300008}$

Sturbelle RT, Pinho DS, Restani RG, Oliveira GR, et al. (2010). Avaliação da atividade mutagênica e antimutagênica da Aloe vera em teste de Allium cepa e teste de micronúcleo em linfócitos humanos binucleados. Rev. Bras. Farmacogn. 20: 409-415. http://dx.doi.org/10.1590/S0102-695X2010000300019

Tian B and Hua Y (2005). Concentration-dependence of prooxidant and antioxidant effects of aloin and Aloe-emodin on DNA. Food Chem. 1: 413-418. http://dx.doi.org/10.1016/j.foodchem.2004.06.018

Tice RR, Agurell E, Anderson D, Burlinson B, et al. (2000). Single cell gel/comet assay: guidelines for in vitro and in vivo genetic toxicology testing. Environ. Mol. Mutagen. 35: 206-221. http://dx.doi.org/10.1002/(SICI)10982280(2000)35:3<206::AID-EM8>3.0.CO;2-J

Toliopoulos I, Simos Y, Verginadis I, Oikonomidis S, et al. (2012). NK cell stimulation by administration of vitamin $\mathrm{C}$ and Aloe vera juice in vitro and in vivo: A pilot study. J. Herb. Med. 2: 29-33. http://dx.doi.org/10.1016/j. hermed.2012.04.002

Tomasin R and Gomes-Marcondes MCC (2011). Oral administration of Aloe vera and honey reduces Walker tumour growth by decreasing cell proliferation and increasing apoptosis in tumour tissue. Phytother. Res. 25: 619-623. http:// dx.doi.org/10.1002/ptr.3293

Von Borstel RC, Drake JW and Loeb LA (1996). Foreword. Mutat. Res. 350: 1-3. http://dx.doi.org/10.1016/00275107(96)90041-X

Yu Z, Jin C, Xin M and Jianmin H (2009). Effect of Aloe vera polysaccharides on immunity and antioxidant activities in oral ulcer animal models. Carbohydr. Polym. 25: 307-311. http://dx.doi.org/10.1016/j.carbpol.2008.07.029

Genetics and Molecular Research 15 (3): gmr.15038522 